\title{
Histopathological Studies on Some Vital Organs of Mice Exposed To Extremely Low Frequency Magnetic Field
}

\author{
(1) Aida Abd El-Karim Salama, (2) Neveen Hussein Mahmoud, \\ ${ }^{(3)}$ Hoda Mahmoud Shoman and ${ }^{(4)}$ Asmaa Abdel-Hadi Dahshan \\ ${ }^{(1)}$ Biophysics Dep. ${ }^{(2),(3)}$ and ${ }^{(4)}$ Zoology Dep. \\ Faculty of Science AL-Azhar University for Girls
}

\begin{abstract}
Twenty five male Swiss albino mice were used in this study to detect the effect of extremely low frequency magnetic field (ELFMF) 2 milli Tesla-50 Hertz $(2 \mathrm{mT}, 50 \mathrm{~Hz}) 8$ hours/day at different time intervals. Mice were divided into five groups, control group and 4 treated groups, two groups represented the direct effect of (ELFMF) and the other two represented the late effect. The direct effect groups were sacrificed direcly after the end of exposure to (ELFMF), while the late effect groups were sacrificed after certain duration period of the exposure away from (ELFMF). In the present work, histopathological studies revealed severe degeneration changes in kidney, spleen and testes of all groups of mice direct and late effect groups and no sign of complete recovery could be detected in the late effect groups. Glomerular volume, number of glomeruli, relative glomerular blood volume (RGBV) of the kidney; and the mean number cells of spermatogenesis cells of the testes were calculated in control and treated groups. The histopathological changes observed in the kidney, spleen and testes of treated mice were less in direct effect groups than that observed in late effect groups.
\end{abstract}

\section{Introduction}

Researches and clinical experiences confirm the interaction of magnetic environment with living organisms causing significant biological effects depending on the field strength and duration of exposure (Graham et al,. 1994 and King, 1998). One of the critical issues is the possibility that such fields may adversely affect the cell membrane receptors and permeability leading to disturbing the physiological processes in organisms. Kang et al. (1997), and Sonnier et al (2000), studied the biological effect of magnetic field $0.5 \mathrm{~T}$ at 7 $\mathrm{Hz}$ on kidney of mice, they found that degenerated tubules were scattered in the cortical area where a little change was observed in glomeruli in the cortex and collecting tubules in the medulla.

Iuldashev (2002) proved that $50 \mathrm{~Hz}$ magnetic field of $15 \mathrm{mT}$ affect the mitotic division of proximal tubules. He recorded a change in the ratio of the total area glomerular capillaries to glomerular area indicating asynchronism of their filling with blood. Somosuy et al, (2004) proved that
$50 \mathrm{~Hz}$ MF affected the cell junction protein complex by modification of their distribution.

Peterson, et al. (1992), transplantation of bone marrow cells of magnetic-fieldexposed mice led to increased numbers of spleen colonies (CFU-S 7d) in conditioned recipient mice.El-Kholy (1999) studied the effect of $50 \mathrm{~Hz}$ magnetic field on spleen structural changes of mice exposed to $\mathrm{X}$ radiation, he found cytoplasmic nuclear degeneration. Ivanova and Kartasheve (1991) and Lokhmatova and Pastukhova (1993) observed chronic influence of $50 \mathrm{~Hz}$ ELFMF on spermatogenesis process of mice testis, disturbances in spermatogonia and spermatids as well as reduction of the number of testosterone producing cells. Zsolt et al, (2004) found histopathological alterations in testis, epididymes, adrenal, prostates and pituitary glands of male mice exposed to $50 \mathrm{~Hz} \mathrm{MF}$.

The present work was planned to clarify the effect of extremely low frequency $2 \mathrm{mT}, 50 \mathrm{~Hz}$ magnetic field on 
the histopathology of some vital organs of Swiss albino rats such as kidneys, spleen and testes.

\section{Materials and Methods}

Twenty- five male mice aged between 6-8 weeks and weighting 35-50 gm were used in the present study. Mice were divided into five groups, the control group and 4 treated groups. Each group included 5 mice. In the treated groups, the whole bodies were exposed to (ELFMF) $2 \mathrm{mT}, 50$ $\mathrm{Hz}$ (8 hours/day) for different time intervals.

Mice were housed in 5 plastic cages and fed with a standard diet. The device of exposure consists of a coil placed on a wooden rack which has 320 turns of 0.8 mm cupper wire wounded around a cupper cylinder of $2 \mathrm{~mm}$ thick, $40 \mathrm{~cm}$ in diameter and $40 \mathrm{~cm}$ in length. The cylinder wall was earthed to eliminate the effects of electric field. The ends of the coil were connected to a variac which was fed from the mains (220 Vpp and $50 \mathrm{~Hz}$ ) to produce (ELFMF). The magnetic field strength inside the magnetic chamber (where the animals were housed) was adjusted by changing the voltage across the coil by the variac. During exposure, the mice cages were placed in the middle of the coil to receive a homogenous ELFMF.

\section{Group (A) control group}

Direct effect groups: Group (B) was exposed to ELFMF for 5 days $8 \mathrm{hrs} /$ day and group (C) was exposed to ELFMF for 20 days 8 hrs / day

Late effect groups: Group (B1) was exposed to ELFMF for 5 days 8hrs/day, and then kept unexposed for 45 days; while group $\left(\mathrm{C}_{1}\right)$ was exposed to ELFMF for 20 days $8 \mathrm{hr} /$ day, and was kept unexposed for 45 days.

Fresh specimens of kidneys, spleens and testes were taken from control and treated groups of mice and prepared according to (Drury e tal., 1973) fixed in Boun's fluid and stained by Harris's hematoxylin and eosin (Culling et al., 1985).

All glomerular profiles in a given sagittal section of kidney was classified as superficial subcapsular and midcortical regions. The total number of glomeruli in a mid-sagittal section was enumerated. Average glomerular volume (V) was calculated using the method of Palkovits and Zolani (1963) and Zaki (1993). This is based upon the two known axial measurements, $\mathrm{L}$ and $\mathrm{B}$, while the third axis is assumed equal to one-half of $\mathrm{B}$. where $\mathrm{T}$ is constant (3.14).

$$
V=\frac{T}{6}(\sqrt{L B})^{3}
$$

The relative glomerular blood volume capacity (RGBV) was calculated by multiplying the average glomerular volume by the average number of glomeruli for each zone in a mid-sagittal longitudinal section (Altschuler et al., 1979). The data obtained were statistically analyzed according to Sendecor (1987). Differences between the group means were assessed using t-test. $\mathrm{P} \leq 0.01$ was considered significant, and the percentage of change was calculated as follows:

\section{$\%=$ Percentage of change $=$}

Data of treated - Data of control

\section{Data of control}

X 100

The num bers of the spermatogonia, primary and secondery spermat ocytes and spermatid were colculated according to Campagnolo et al , (2001).

\section{Results}

Kidney:

Histological examination of the normal structure of the kidney cortex of control (group A) was illustrated in figure (1).

Microscopical examination of the kidney cortex in group (B) revealed some 
degenerative changes such as prominent internal hemorrhage, atrophied and vacuolated convoluted tubules. Intertubular alterations included the occurrence of collapsed glomeruli, and congested gromerular capillaries (Fig. 2). Group(C) showed focal areas of necrosis, hypertrophied glomeruli and nuclear degeneration (Fig.3).

In group (B1) multidegenerated areas and hemosiderin deposition were observed (Fig.4). Degeneration of tubules and glomeruli was still observed in group (C1) and little sign of recovery was detected (Fig.5).

\section{The relative glomerular blood volume (RGBV):}

The relative volume was calculated assuming that the glomerular shape is spherical. Table (1) and histograms (1 \& 2) show the relative glomerular blood volume. In control mice the volume is $8.03 \times 10^{7}$ and $9.64 \times 10^{7}$ in superficial and midcortical regions respectively. While in group (B) the percentage of change in RGBV was decreased and reached 11.5 in superficial and 6.48 in mid- cortex. These changes were increased in the other three groups $(\mathrm{C}, \mathrm{B} 1$ and $\mathrm{C} 1)$ and reached -29.81 in superficial and -30.47 in med-cortical of group (C1).

\section{Spleen:}

Figure (6) showed the normal structure of spleen of mice in group (A). It was surrounded by thick fibro-elastic of connective tissues (CT) capsule with some myofibroblasts and a covering mesothelium. Internally, thick CT trabeculae bear branches of the splenic artery and veins, with normal white and red pulps. In Group (B) histopathological changes of mice spleen were represented by internal haemorrhage and ill defined white pulp. Complete loss of lymphoid follicular structure, and increased number of megakaryocytes were observed (Fig.7).

$\operatorname{Group}(\mathrm{C})$ revealed thickened splenic capsule with subscapular dark pigments possibly haemosiderin and megakaryocytes, vacuolation was prominent in different types of cells (Fig.8).

In group (B1) massive expansion of red pulp and restricted white pulp were detected, vacuolation was also observed (Fig.9).

Group ( $\left.\mathrm{C}_{1}\right)$ the appearance of degeneration was common all over the spleen tissue with some of improvement (Fig.10).

\section{The Testis:}

Normal mice testes (Group A) showed normal arrangement of spermatogenic layers and Leydig cells inbetween seminiferous tubules (Fig.11). Group (B) revealed fragmented tails of some spermatozoa and well developed Leydig cells (Fig.12). Group (C) the pathology of this group was represented by disturbed spermatogenesis and reduction in sperms (Fig.13). Group (B1) revealed continuous mitotic disturbance in all stages of spermatogenesis accompanied by faintly stained nuclei with hypertrophic Leydig cells (Fig.14). Group (C1) was characterized by increasing activity in mitotic division of primay spermatocytes accompanied by wide intertubuler spaces (Fig.15).

In table (2) and histogram (3), the mean number of spermatogonia cells, primary spermatocytes, secondary spermatocytes and spermatids in control were $106.8 \pm 11.63,100.2 \pm 723,195.6 \pm 11.63$ and $214.8 \pm 15.98$ respectively. No sign of significant changes in the mean number in group (B) except in the spermatids which showed significant change. The average percentage of change decreased gradually in groups $(\mathrm{C}),(\mathrm{B} 1)$, and reached maximum decrease in group $(\mathrm{C} 1)$. 
Table (1): Glomerular volume, number of glomeruli and relative glomerular blood volume (RGBV) for superficial and mid-cortex zones of the control and treated groups

\begin{tabular}{|c|c|c|c|c|c|c|c|}
\hline \multirow{2}{*}{ Groups } & & \multicolumn{3}{|c|}{ Superficial cortex } & \multicolumn{3}{|c|}{ Mid-cortex } \\
\hline & & $\begin{array}{c}\text { Glomerular } \\
\text { Volume }\end{array}$ & $\begin{array}{c}\text { Number of } \\
\text { glomeruli }\end{array}$ & RGBV & $\begin{array}{c}\text { Glomerular } \\
\text { Volume }\end{array}$ & $\begin{array}{c}\text { Number of } \\
\text { glomeruli }\end{array}$ & RGBV \\
\hline \multirow{2}{*}{$\mathbf{A}$} & Average & $4.41 \mathrm{E}+05$ & $1.82 \mathrm{E}+02$ & $8.03 \mathrm{E}+07$ & $6.06 \mathrm{E}+05$ & $1.60 \mathrm{E}+02$ & $9.64 \mathrm{E}+07$ \\
\hline & SD. & $6.22 \mathrm{E}+04$ & $9.96 \mathrm{E}+00$ & $1.34 \mathrm{E}+07$ & $1.02 \mathrm{E}+05$ & $7.93 \mathrm{E}+00$ & $1.44 \mathrm{E}+07$ \\
\hline \multirow{5}{*}{ B } & Average & $3.91 \mathrm{E}+05$ & $1.81 \mathrm{E}+02$ & $7.11 \mathrm{E}+07$ & $5.70 \mathrm{E}+05$ & $1.58 \mathrm{E}+02$ & $9.02 \mathrm{E}+07$ \\
\hline & SD. & $1.13 \mathrm{E}+05$ & $9.18 \mathrm{E}+00$ & $2.15 \mathrm{E}+07$ & $6.48 \mathrm{E}+04$ & $7.42 \mathrm{E}+00$ & $1.12 \mathrm{E}+07$ \\
\hline & t-test & $7.98 \mathrm{E}-02$ & $2.24 \mathrm{E}-01$ & $7.90 \mathrm{E}-02$ & $1.80 \mathrm{E}-01$ & $1.74 \mathrm{E}-01$ & $1.53 \mathrm{E}-01$ \\
\hline & Probability & Non Sig. & Non Sig. & Non Sig. & Non Sig. & Non Sig. & Non Sig. \\
\hline & $\%$ of change & -11.18 & -0.39 & -11.50 & -5.89 & -1.06 & -6.48 \\
\hline \multirow{5}{*}{$\mathbf{C}$} & Average & $3.82 \mathrm{E}+05$ & $1.80 \mathrm{E}+02$ & $6.87 \mathrm{E}+07$ & $5.20 \mathrm{E}+05$ & $1.59 \mathrm{E}+02$ & $8.29 \mathrm{E}+07$ \\
\hline & SD. & $1.11 \mathrm{E}+05$ & $1.02 \mathrm{E}+01$ & $1.97 \mathrm{E}+07$ & $9.31 \mathrm{E}+04$ & $1.05 \mathrm{E}+01$ & $1.74 \mathrm{E}+07$ \\
\hline & $\mathrm{t}$-test & $4.73 \mathrm{E}-02$ & $1.99 \mathrm{E}-01$ & $2.53 \mathrm{E}-02$ & $1.02 \mathrm{E}-02$ & 3.04E-01 & $1.12 \mathrm{E}-02$ \\
\hline & Probability & Non Sig. & Non Sig. & Non Sig. & Non Sig. & Non Sig. & Non Sig. \\
\hline & $\%$ of change & -13.33 & -0.99 & -14.47 & -14.22 & -0.56 & -14.01 \\
\hline \multirow{5}{*}{ B1 } & Average & $3.45 \mathrm{E}+05$ & $1.82 \mathrm{E}+02$ & $6.25 \mathrm{E}+07$ & $4.56 \mathrm{E}+05$ & $1.60 \mathrm{E}+02$ & $7.28 \mathrm{E}+07$ \\
\hline & SD. & $8.57 \mathrm{E}+04$ & $8.88 \mathrm{E}+00$ & $1.53 \mathrm{E}+07$ & $1.13 \mathrm{E}+05$ & $8.87 \mathrm{E}+00$ & $1.73 \mathrm{E}+07$ \\
\hline & t-test & $5.84 \mathrm{E}-03$ & $4.75 \mathrm{E}-01$ & $5.93 \mathrm{E}-03$ & 7.86E-03 & $3.91 \mathrm{E}-01$ & $8.35 \mathrm{E}-03$ \\
\hline & Probability & Sig. & Non Sig. & Sig. & Sig. & Non Sig. & Non Sig. \\
\hline & $\%$ of change & -21.75 & -0.11 & -22.14 & -24.76 & 0.25 & -24.55 \\
\hline \multirow{5}{*}{ C1 } & Average & $3.13 \mathrm{E}+05$ & $1.81 \mathrm{E}+02$ & $5.64 \mathrm{E}+07$ & $4.16 \mathrm{E}+05$ & $1.61 \mathrm{E}+02$ & $6.70 \mathrm{E}+07$ \\
\hline & SD. & $8.36 \mathrm{E}+04$ & $1.01 \mathrm{E}+01$ & $1.51 \mathrm{E}+07$ & $8.93 \mathrm{E}+04$ & $8.41 \mathrm{E}+00$ & $1.52 \mathrm{E}+07$ \\
\hline & t-test & $1.31 \mathrm{E}-03$ & $1.35 \mathrm{E}-01$ & $1.30 \mathrm{E}-03$ & $5.42 \mathrm{E}-05$ & $1.11 \mathrm{E}-01$ & $4.50 \mathrm{E}-05$ \\
\hline & Probability & Sig. & Non Sig. & Sig. & Sig. & Non Sig. & Sig. \\
\hline & $\%$ of change & -29.06 & -0.71 & -29.81 & -31.34 & 0.75 & -30.47 \\
\hline
\end{tabular}

Non. Sig. $=$ Non-significant $(\mathrm{P}>0.01)$; and Sig. =significant $(\mathrm{P} \leq 0.01)$

Data of treated - Data of control

$\%=$ Percentage of change $=$ X 100

Data of control 


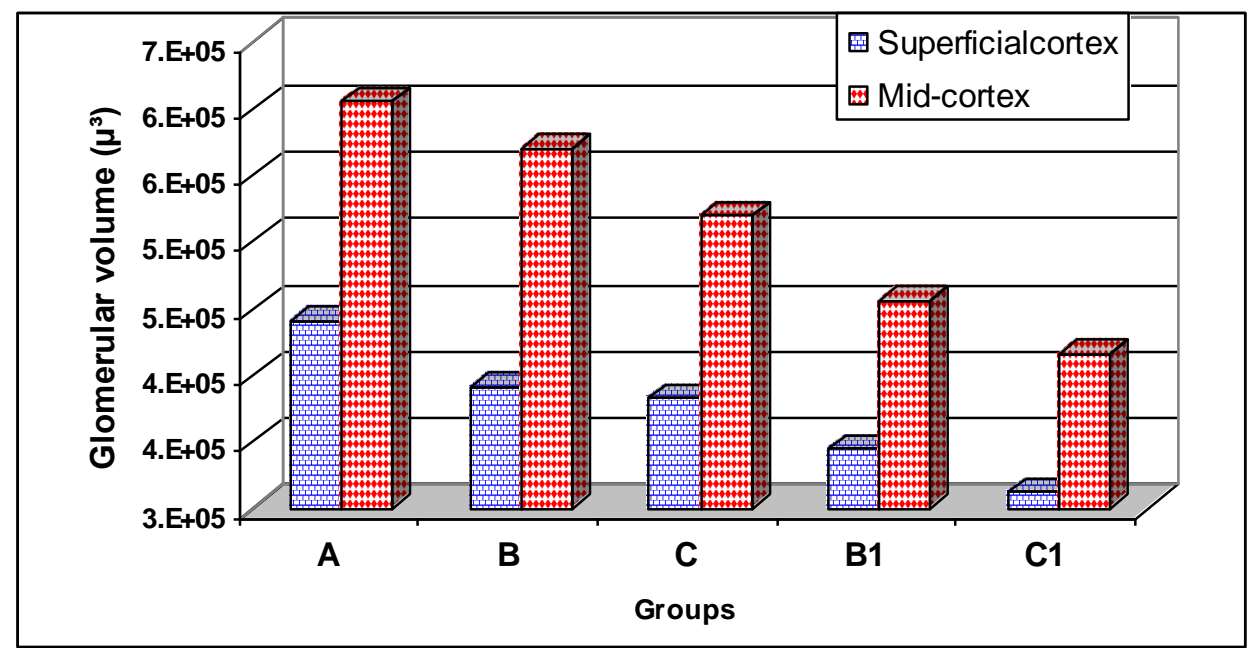

Histogram (1): Showing the mean glomerular volume $\left(\mu^{3}\right)$ in superficial and mid-cortex in control and treated groups.

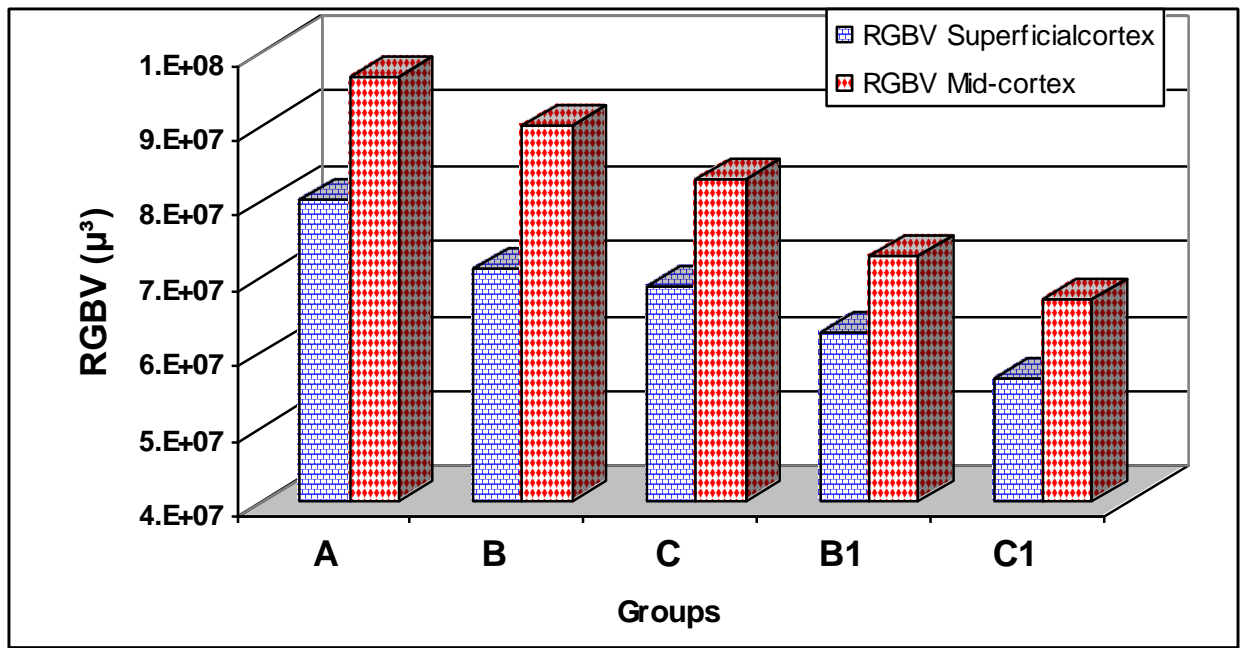

Histogram (2): Showing the relative glomerular blood volum (RGBV) in superficial and mid-cortex in control and treated groups. 
Table (2): Statistical analysis of the mean number cells of spermatogenesis in control and treated groups.

\begin{tabular}{|c|c|c|c|c|c|}
\hline Groups & & $\begin{array}{l}\text { Spermatogonia } \\
\text { (Sp) }\end{array}$ & $\begin{array}{c}\text { Primary } \\
\text { Spermatocyte } \\
\text { (SP1) }\end{array}$ & $\begin{array}{c}\text { Secondary } \\
\text { Spermatocyte } \\
(\text { Sp2) }\end{array}$ & Spermatid \\
\hline \multirow{2}{*}{$\mathbf{A}$} & Mean & 106.800 & 100.200 & 195.800 & 214.800 \\
\hline & SD. & 11.628 & 7.225 & 11.628 & 15.975 \\
\hline \multirow{4}{*}{ B } & Mean & 98.800 & 93.000 & 186.600 & 193.800 \\
\hline & SD. & 7.855 & 9.798 & 13.686 & 18.226 \\
\hline & t-test & 0.113 & 0.056 & 0.176 & $0.006^{*}$ \\
\hline & $\%$ of change & -7.491 & -7.186 & -4.699 & -9.777 \\
\hline \multirow{4}{*}{ C } & Mean & 83.400 & 107.000 & 176.600 & 185.200 \\
\hline & SD. & 9.290 & 8.972 & 23.061 & 10.710 \\
\hline & t-test & $0.002 *$ & 0.068 & 0.070 & $0.000 *$ \\
\hline & $\%$ of change & -21.910 & 6.786 & -9.806 & -13.780 \\
\hline \multirow{4}{*}{ B1 } & Mean & 88.800 & 116.000 & 157.800 & 157.200 \\
\hline & SD. & 8.167 & 17.044 & 10.010 & 9.094 \\
\hline & $\mathrm{t}$-test & $0.006^{*}$ & $0.041^{*}$ & $0.001 *$ & $0.000 *$ \\
\hline & $\%$ of change & -16.854 & 15.768 & -19.408 & -26.816 \\
\hline \multirow{4}{*}{ C1 } & Mean & 70.800 & 139.800 & 155.400 & 132.200 \\
\hline & SD. & 8.899 & 33.522 & 21.232 & 18.144 \\
\hline & t-test & $0.000^{*}$ & 0.032 & 0.015 & $0.001 *$ \\
\hline & $\%$ of change & -33.708 & 39.521 & -20.633 & -38.454 \\
\hline
\end{tabular}

*. =significant $(\mathrm{P} \leq 0.01)$

Data of treated - Data of control

$\%=$ Percentage of change= ------------------------------ X 100

Data of control

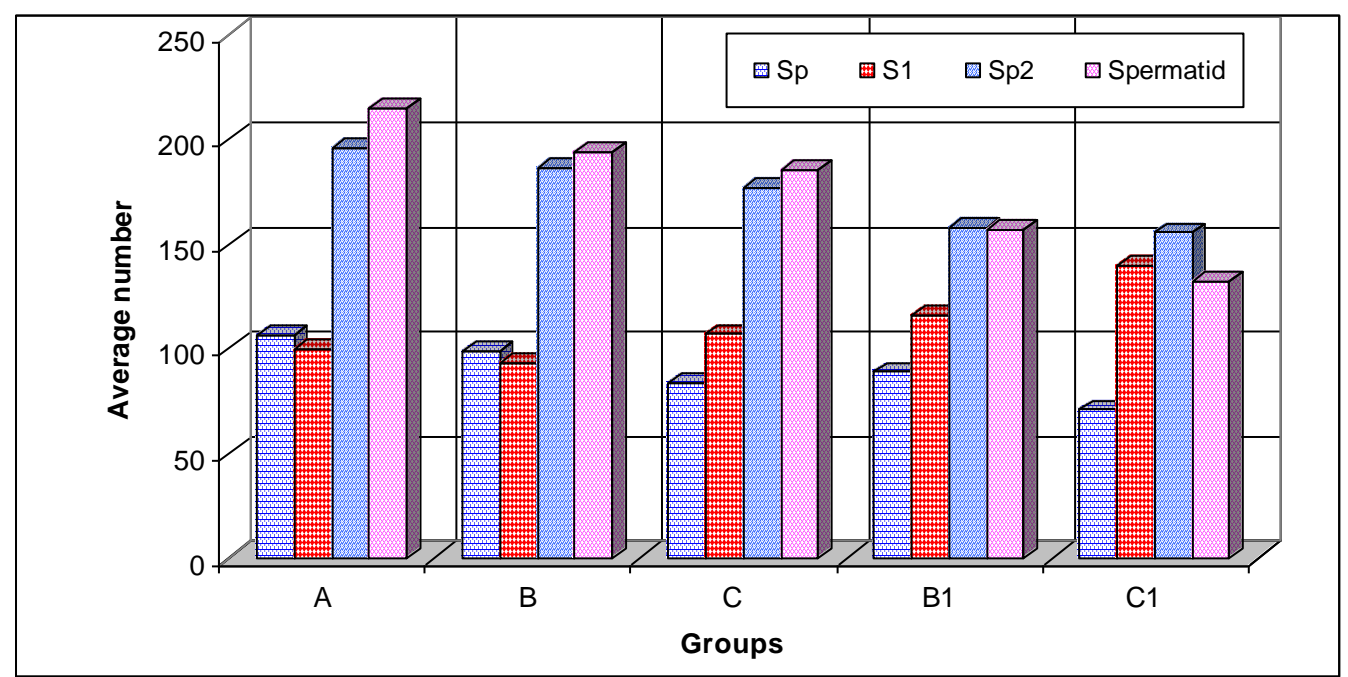

Histogram (3): Showing the mean number cells of spermatogenesis in control and treated groups. 


\section{List of Figures:}

Fig. (1): Photomicrograph of control mice kidney (group A) showing normal structure of glomerulus (g) surrounded by Bowman's capsule (B) proximal convoluted tubule (pc) and distal convoluted tubule dc. (H\&E X 200).

Fig. (2): Photomicrograph of mice kidney (group B) showing some cellular changes as prominent internal hemorrhage $(\uparrow)$, some atrophied tubules ( $t$ ), degenerated tubules (d) and others are vacuolated especially at the margin of cortex. Glomeruli appeared normal (H\&E X 200).

Fig. (3): Photomicrograph of mice kidney (group C) showing focal areas of necrosis (n), karyolitic nuclei $(\mathrm{k})$ with granulated and marginal chromatin $(\mathrm{m})$ ruptured cell membrane with vacuolated cytoplasm (v), hydropic degeneration (d), pyknotic nuclei (p). Glomeruli are hypertrophied (g). (H\&E X 200).

Fig. (4): Photomicrograph of mice kidney (group B1) showing multi degenerated area (d) abnormal aggregated nuclei (n) with faintly stained cytoplasm, some nuclei are pyknotic (P) other are karyolitic (k). hemosiderin deposition ( $\uparrow) .(H \& E$ X 400).

Fig. (5): Photomicrograph of mice kidney (group $\mathrm{C}_{1}$ ) showing highly hypertrophied glomeruli (g) with ill defined Bowman's capsule (B), atrophied convoluted tubules (t) and degenerated cells (d). (H\&E X 200).

Fig. (6): Photomicrograph of control mice spleen (group A) showing normal white pulps (wp) with well developed arteriole (a), red pulps (rp), trabeculae (t). (H\&E X 200).

Fig. (7): Photomicrograph of mice spleen (group B) showing internal hemorrhage $(\uparrow)$ ill defined white pulps and a complete loss of lymphoid follicular structure mega karyocytes (mk).

(H\&E X 200).
Fig. (8): Photomicrograph of mice spleen (group C) showing thickening of splenic capsule (c), subcapsular hemosiderin granules $(\uparrow)$, prominent mega karyocytes (mk) and vacuolated cells (v). (H\&E X 200).

Fig. (9): Photomicrograph of mice spleen (group $\mathrm{B} 1$ ) showing massive expansion of red pulp (rp), some atrophied nuclei (t) and ill defined white pulp.

Fig. (10): Photomicrograph of mice spleen (group $\mathrm{C} 1$ ) showing numerous degenerated areas (d) with signs of hemolysis $(\uparrow)$ some nuclei are deeply stained (1) others contained signet ring (2) some are atrophied (3). (H\&E X 400).

Fig. (11): Photomicrograph of control mice testis (group A) showing normal arrangement of different spermatogenic layers supported by Sertoli cells (st) in seminiferous tubules and Leydig cells (LC). (H\&E X 400).

Fig. (12): Photomicrograph of mice testis (group B) showing fragmented tails of some spermatozoa ( $\uparrow)$ with well developed Leydig cells (LC). (H\&E X 400).

Fig. (13): Photomicrograph of mice testis (group C) showing disturbance spermatogenic layers and highly reduced number of sperms (H\&E X 200).

Fig. (14): Photomicrograph of mice testis (group B1) showing a lot of mitotic division in primary spermatocytes $(\uparrow)$ increased number of secondary spermatocytes, spermatides and hypertrophic Leydig cells (LC). (H\&E $X$ 400).

Fig. (15): Photomicrograph of mice testis (group $\mathrm{C}_{1}$ ) showing increased numberof spermatogenic layers with crowded sperms near the lumen of the tubules $(\uparrow)$ and most of 1 ry spermatocytes showing mitotic activity, reduced number of Leydig cells and wide intertubular spaces. (H\&E X 400). 

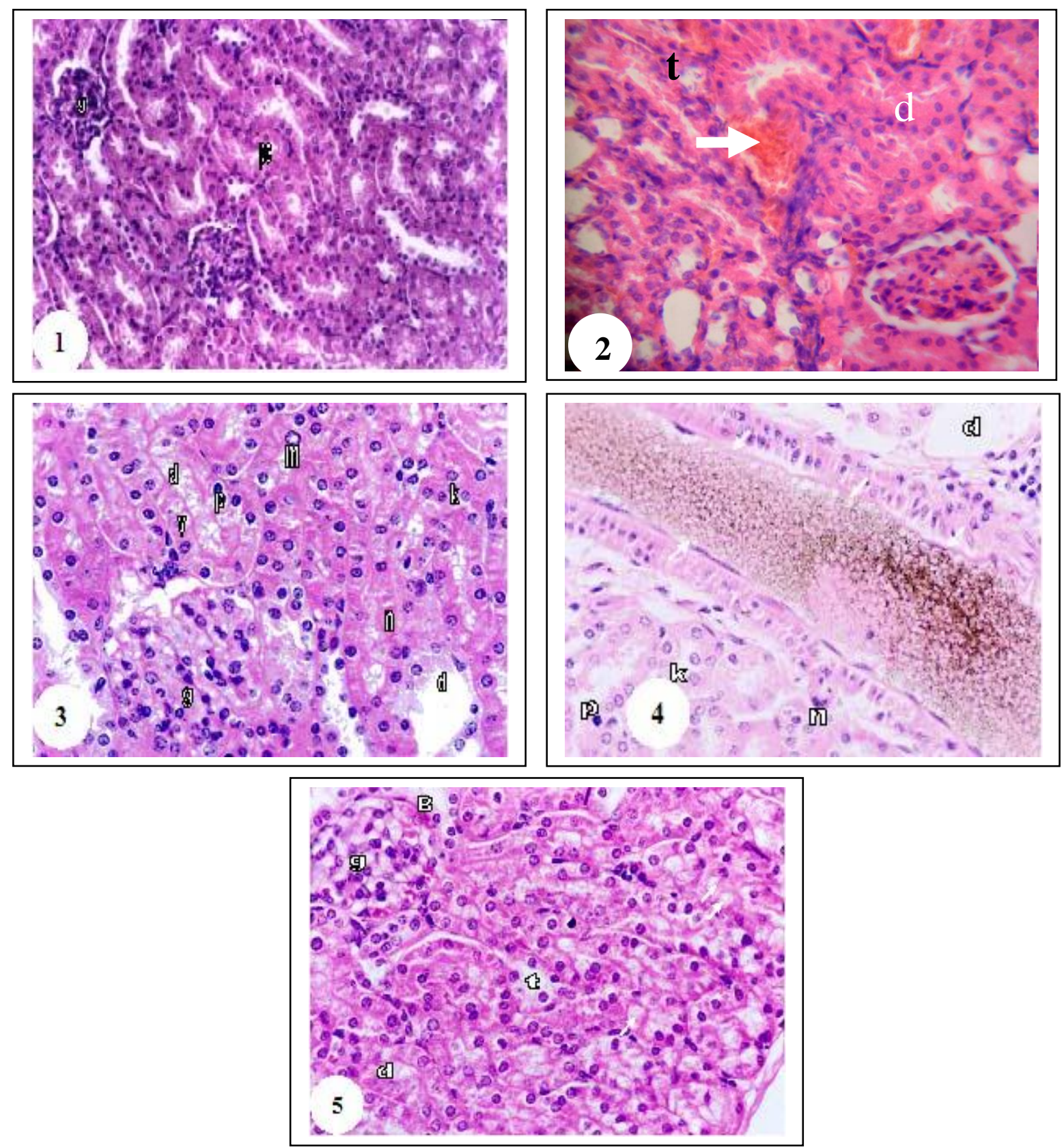
Histopathological Studies on Some Vital...........
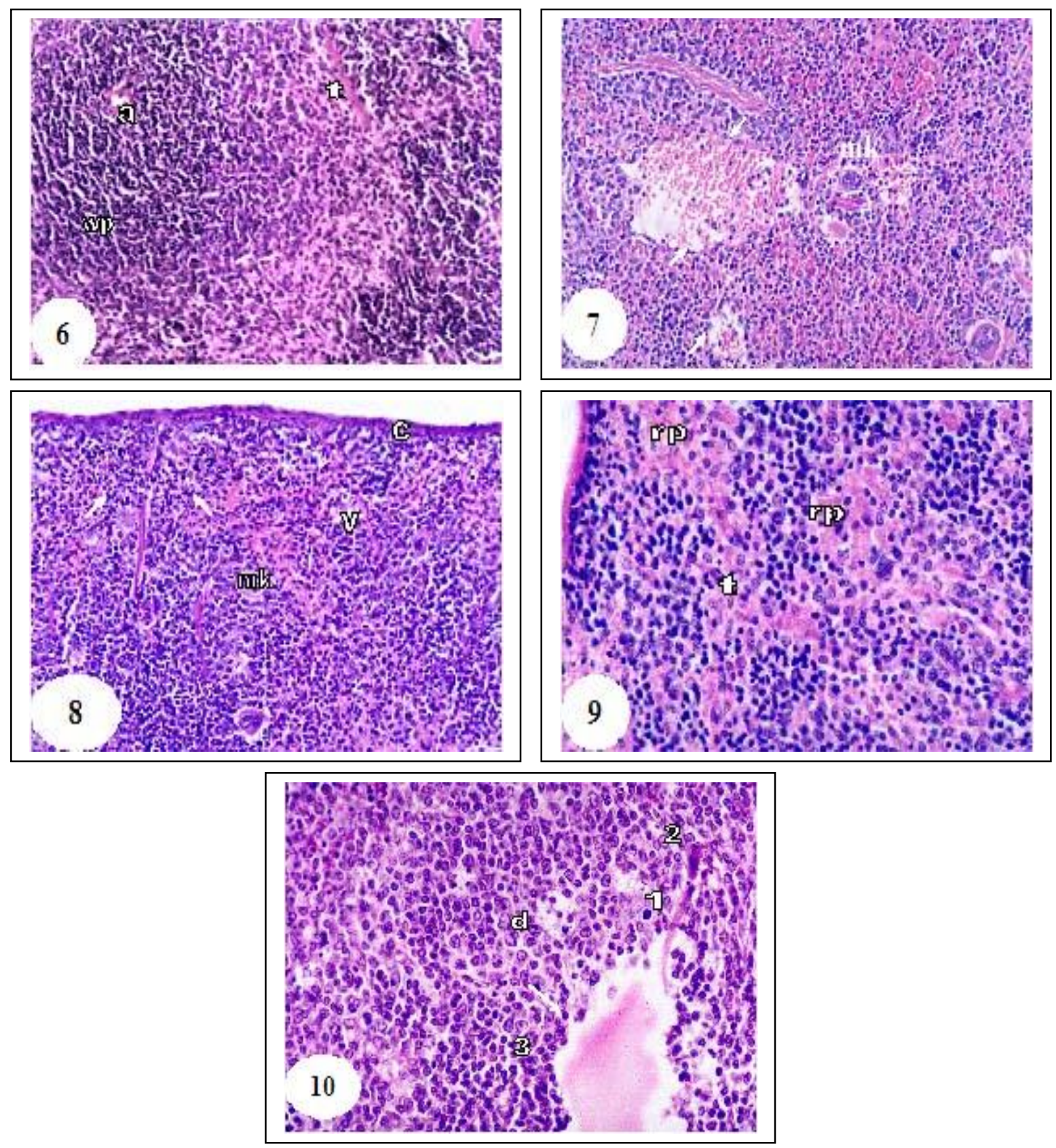

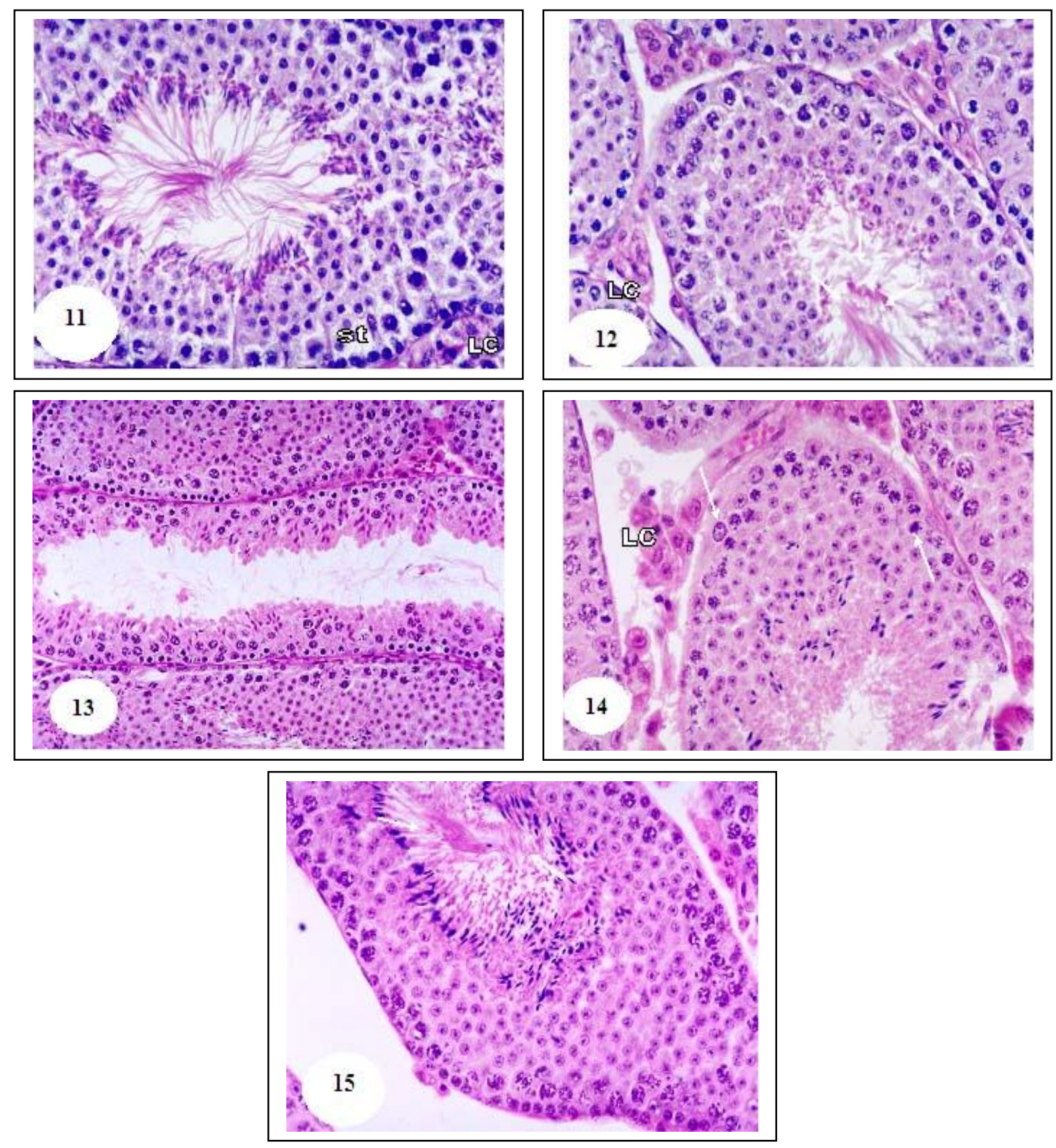


\section{Discussion}

In the present study, the extremely low frequency magnetic fild (ELFMF) was chosen because it has been encountered in many places such as medical practice and new technologies in use nowadays, (Juutilaineny, 1991).

The degree of pathological changes in the kidney of mice exposed to $2 \mathrm{mT}-50 \mathrm{~Hz}$ ELFMF ( 8 hrs/day) was observed in direct and late effect groups. The direct effect groups were characterized by prominent nuclear karyolysis, pyknosis, vacuolation and hydropic degeneration. However glomeruli appeared normal in its structures except in group (C), hypertrophied glomeruli with tubular cell necrosis were detected. The kidney of late effect groups revealed severe pathology i.e. multi degenerated areas of renal tubules with few fibrosis in some of them, appearance of hemosiderin like granules and increase internal hemorrhage and small sign of recovery was detected. These pathological findings are almost similar to the results reported by Kang et al., (1997). On the other hand the present work confirmed that the percentage of changes in RGBV in superficial and mid-cortex of kidney in the treated mice, were increased in each direct and late effect groups. However this result agreed with the findings madeby Iuldashev, (2002).

The exposure of mice to $2 \mathrm{mT}, 50 \mathrm{~Hz}$ ELFMF ( $8 \mathrm{hrs}$ /day) was responsible for the severe and acute hemorrhage, nuclear degeneration and the increase in production of megakaryocytes in the spleen of direct effect groups or in late effect ones. In this regard (Nardi, 2004) recorded changes in the spleen of young rats exposed to high energy shock wave, in red pulp (increased number of megakaryocytes and erythroblasts nests). The results are also similar to that obtained by Amer (1995), Yedidia et al (1998) and El-Kholy (1999), they found necrotic degeneration, thickening of capsules and appearance of haemosiderin in spleen of rabbit treated with bentazon.

Extremely low frequency magnetic field has an expected hazard effect on testis which is considered a target organ among the more sensitive organs in the body because it contains rapidly dividing cells. In the present study, the effect of ELFMF on testes of exposed mice was obvious on the direct and late effect groups. The results indicated significant disturbance in spermatogenic process with detached tails of sperms and reduction in Leydig cells was accompanied by wide intertubular spaces. The results were confirmed with the data obtained by Ivanova et al., (1991), Lokhmatova et al. (1993); Zsolt et al., (2004) and Chung, et al. (2005).

The numerical value of spermatogonia, primary spermatocytes, secondary spermatocytes and spermatids in treated groups were decreased than control. Farias, et al. (2005); evaluated these cha-nges to metabolic changes in spermatogenic cells, in all stages of the spermatogenic cycle that confirmed a strong metabolic stress in these cells. The post-meiotic spermatogenic cells loss in the testis correlated with metabolic changes in round spermatids.

From the previous observations we were able to conclude that extremely low level of alternating magnetic field has harmful effect on the biological systems, more studies also needed in this field to determine the limited permissible exposure dose for the security of human health.

\section{References}

1- Altschuler E M, Nagle R B, Brawn E J, Lindstedt, S L and Krutzsch P H (1979): Morphological study of the desert heteromyid kidney with emphasis on the genus Perognathus. Anat. Rec. 184: 461-468.

2- Amer A M (1995): Toxic effect of bentazon on the hematological picture and splenic tissue in rabbits. J. Egypt. Ger. Soc. Zool., 18(c):233-249.

3- Campagnolo L, Russo M A, Puglianiello A, Favale A and Siracusa G (2001): Mesenchymal cell precursors of peritubular smooth muscle cells of the mouse testis can be identified by the presence of the p75 neurotrophin receptor Biol. of Rep. 64: 464-472. 
4- Chung M K, Lee S J, Kim Y B, Park S C, Shin, D H, Kim S H and Kim J C (2005): Evaluation of spermatogenesis and fertility in F1 male rats after in utero and neonatal exposure to extremely low frequency electromagnetic fields. Asian of Androl 7: 189 -197

5- Culling C F A, Allison $\mathbf{R}$ T and Barr W T (1985) : "Cellular Pathology Technique, $4^{\text {th }}$ ed., Mid. County Press, London SW15 printed and bound by Butler\&Tanner Ltd, Frame, Somerset.

6- Drury $\mathbf{R}$ A, Wallington $\mathbf{E} A$ and Cameron S R (1973): Carlton's "Histological Technique" $4^{\text {th }}$ ed., Oxford Univ. Press, New York. Toronto.

7- EL-Kholy S M (1999): Effect of induced $50 \mathrm{~Hz}$, EMF on mice exposed to $\mathrm{X}$ irradiation. Egypt.J.Biophys., 5(1):265-282.

8- Farias J G, Bustos-Obregón E, Orellana R, Bucarey J L, Quiroz E, Reyes J (2005): Effects of chronic hypobaric hypoxia on testis histology and round spermatid oxidative metabolism. Andrologia, 37 (1): 47-52(6)

9- Graham C, Cook M R, Cohen H D and Gerkovich M M (1994): Dose response study of human exposure to $60 \mathrm{~Hz}$ electric and magnetic fields. Bioelecteromagnetics, 15(5):447-463

10- Iuldashev S D (2002): Mitogenic effect and acceleration of stabilization process in the renal glomeruli of hypertrophied kidney after exposure to magnetic field. Morfolgiia, 122(5):84-86

11- Ivanova L A and Kartasheve A G (1991): The effect of alternating electric field of industrial frequency on testides of white mice. Fiziol Zh., 37(6):71-78.

12- Juutilainen J (1991):“Effects of low frequency magnetic fields on embryonic development and pregnancy" Scand.J.Work Environment Health. 17:147-158.

13- Kang G H, Lee C H, Seo J W, Sung R H and Chi J G (1997): In vivo study on the harmful effect of the extremely low frequency unipolar pulsating magnetic field in mice. J.Korean. Med. SCI., 12(2):128-134.
14- King R W (1998): An examination of underlying physical principles. The interaction of power line electromagnetic fields with the human body. Medcal Biol. Mag., 17:67-73.

15- Lokhmatova S A and Pastukhova I R (1993).Morphologic and histoenzymologic analysis of the effect of electrical field on testis of mice. Ekolog. Med., 27(3):50-54.

16- Nardi A C, Ferreira U, Claro J A and Netto N R (2004): Effect of high-energy shock wave on organs adjacent to the kidney in the growing rat. Int. Braz.J.Urol., 30(2):142-147.

17- Palkovits $M$ and Zolani B (1963): Quantitativehistologische methods zur statistishen untersuchung des volumes der nierenglomeruli deren anteil an der nierenrinde. Z. Wiss. Mikroskopie., 65: 342-361.

18- Peterson $\mathbf{H} \mathbf{P}$, Wangenheim $\mathbf{K} \mathbf{H}$ and Feinendegen L E (1992): Magnetic field exposure of marrow donor mice can increase the number of spleen colonies (CFU-S 7d) in marrow recipient mice. Radiat Environ Biophys. 31(1):31-38.

19- Sendecor G W (1987): Statistical Methods $6^{\text {th }}$ ed. Lowa State Univ. Press.

20- Somosuy Z, Forgacs Z, Boynar G, and Horvath G (2004): Alteration of tight and adherens functions on $50 \mathrm{~Hz}$ magnetic field exposure in Madin Darby Carine kidney (MDCK) cells. Scient World. 20:(2-4) 7582.

21- Sonnier H, Kolomytkin O V, and Marino A A (2000): Resting potential of excitable neuroblastoma cells in weak magnetic fields. Cell Mol. Life Sci 57:514-20.

22- Yedidia Y, Ben-Neriah $\mathbf{Y}$ and Jung $\mathbf{S}$ (1998): Primary B cells essentially lack constitutive NF- $\mathrm{x}$ B activity. Eur. J. Immunol. 28: 30-36

23- Zsolt F, Zoltan S, Gyorgyi K and Peter L (2004): Effect of whole-body $50 \mathrm{~Hz}$ magnetic field exposure on mouse Leydig cells Sci. world J. 4(S2):83-90.

24- Zaki T Z (1993): Histological and functional relationship of the kidney of the hedgehogs. Egypt. J. Histol. 16 (2): 451466. 


\section{دراسات نسيجية مرضية على بعض الاعضاء الحيوية للفئران المعرضة للمجال المغناطيسى منخفض التردد}

\section{عايدة عبد الكريم سلامه 1ـ نيفين حسين محمود_2_هدى محمود شومـان 3

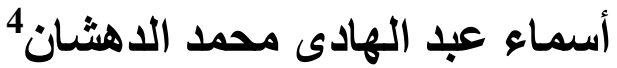

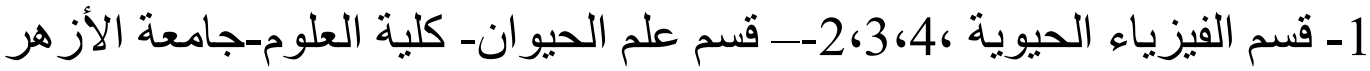
للبنات

أجريت الدر اسة على عدد خمسة و عشرون فأر أبيض سويسرى لمعرفة تأثير

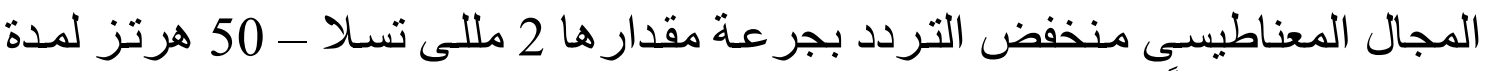

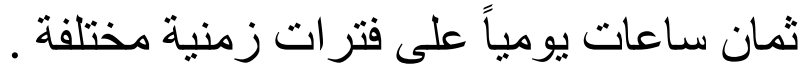

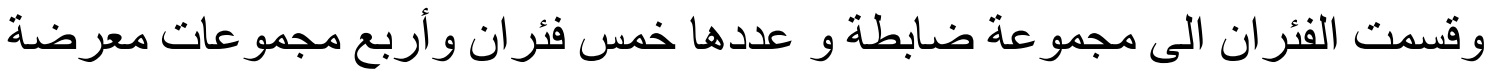

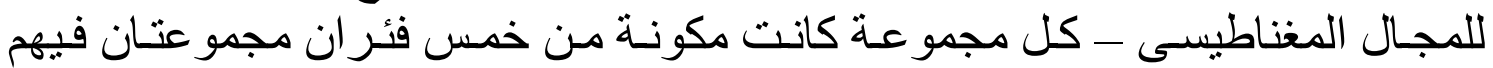

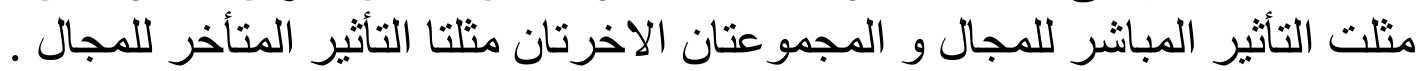

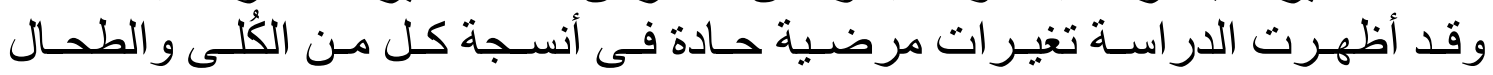

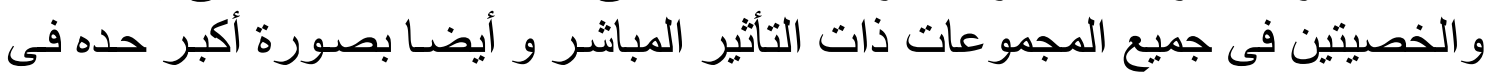

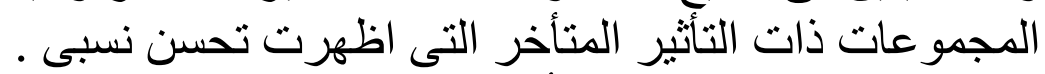

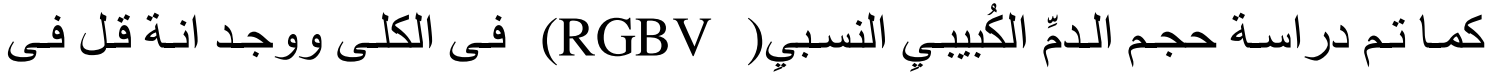

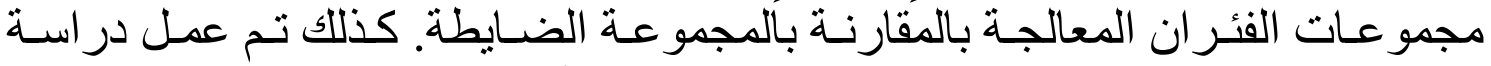

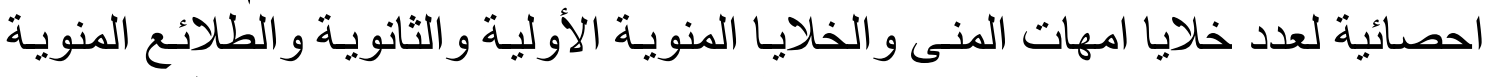

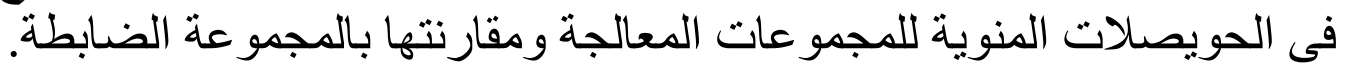

